\title{
Sportskammerater \\ - et tema i forholdet mellem lokale idrætsforeninger og kommunale myndigheder
}

Af Morten Mortensen

»Viføler ikke, at vi hфrer til på skolen. Vi betragter ikke lokaliteterne der, som noget der tilhфrer os, ikke som steder hvor vi rogter en del af det klubliv, som man nu engang ikke kan vare foruden, dersom den rette klubånd og det rette kammeratskab rigtig skal trives og bare frugt til gavn for foreningen og dens arbejde for $i$ al beskedenhed at vare med til, gennem den idratslige indsats at skabe bedre samfundsborgere ${ }^{1}{ }^{1}$

Sådan oplevede Ballerup Idræts Forening i 1961 manglen på eget klubhus. I stedet måtte foreningen tage til takke med skolernes bade- og omklædningsrum. Artiklen, hvorfra dette citat stammer, indgik i en årelang dialog, foreningen havde med kommunen vedrørende $\varnothing$ konomisk støtte til opførelse af et klubhus.

Citatet rummer nogle af de elementer og temaer, som siden begyndelsen af det 20. århundrede og frem til 1970'erne, hvor Fritidsloven for alvor begyndte at fungere, havde været på spil i relationen mellem de kommunale myndigheder og de lokale idrætsforeninger.

$P a ̊$ den ene side fandtes idrætsforeningernes forståelse af sig selv. I idrætsforeningerne blev kammeratskabet opfattet som selve livsgrundlaget for foreningens trivsel, man så skolen som et sted, hvor man ikke kunne føle sig hjemme, og hvor kammeratskabet med dets emotionelle un- dertoner ikke kunne trives. Bag denne opfattelse lå en dybere mentalitetsmæssig oplevelse af, at idrætsforeningen med dens frivillige, lystbetonede og uformelle samvær var væsensforskellig fra skolen og dennes mere formelle og formynderiske facon. For idrætsforeningens medlemmer havde idrætsforeningen netop sin værdi, fordi dens samværsformer var grundlæggende forskellige fra skolens. Lidt hårdt trukket op kan man sige, at skolen som repræsentant for myndighederne symboliserede mange af de værdier, som idrætsforeningerne så sig selv som et alternativ til. Derfor kunne det emotionelt baserede kammeratskab ikke trives inden for skolelokalernes strengt funktionelle og rationelle rammer. Skulle den sande klubånd kunne udfoldes frit, krævede det fysiske rammer, som medlemmerne selv havde skabt. »Den rette klubånd og det rette kammeratskab«, som det blev formuleret, behøvede et klublokale, der var udført »med hjertet $«$. For myndighederne ville gevinsten til gengæld være »bedre samfundsborgere«.

Samtidigt var man en del af det omkringliggende lokalsamfund - ikke mindst de kommunale myndigheder - hvori idrætsforeningerne indgik i en kamp om ressourcer med andre foreninger og institutioner. Over en lang periode antog denne kamp en moralsk karakter, om hvem der var bedst til at tage sig af ungdommen i fritiden. For idrætsforeningerne var det der- 
for uhyre vigtigt at blive vurderet som respektable og ansvarsfulde aktører på det sociale og fritidsmæssige område og ikke kun blive opfattet som et sted, hvor voksne mænd fjollede unyttigt rundt. Derfor indeholdt udsagn som ovenstående citat ofte en pointering af idrætsforeningens samfundsbetydning.

De rettigheder og aftaler om $\varnothing$ konomisk støtte med kommunen, de fleste idrætsforeninger i dag næsten tager som en selvfølge, var opnået i en langsomt fremadskridende proces over en lang årrække, hvor lokale idrætsforeninger med større eller mindre held vandt den lokale magtkamp om at kunne give børn og unge en god fritidsbeskæftigelse.

Tilsyneladende var den politik, som de kommunale myndigheder anvendte over for idrætsforeningerne, præget af pragmatisme og planløshed. Man tog stilling fra sag til sag og koncentrerede sig om at anlægge idrætsfaciliteter. En egentlig selvstændig politisk plan eller samlet idé i forhold til idrætten eksisterede ikke i de politiske partier. Det var næsten, som om der herskede en modvilje mod at føre en samlet målbevidst idrætspolitik, og man kan spørge, hvorfor så godt som alle (kommunal)politikere næsten uanset politisk tilhørsforhold var så tilbageholdende med at formulere en decideret idrætspolitik.

Måske skal svaret findes i, at idrætsforeningernes selvforståelse på en lang række områder blev delt af det omgivende samfund og i høj grad også af politikerne. Lidt højtideligt formuleret kan man sige, at idrætsforeningerne repræsenterede en mulighed for - her og nu - at praktisere en samværsform baseret på lyst, engagement og frivillighed. Idrætsforeningernes opfattelse af kammeratskab, frivillighed, socialt fællesskab og autonomi kan ses som led i en langt bredere mentalitetsmæssig omform- ningsproces, hvorigennem opfattelsen og oplevelsen af individet som subjekt blev etableret. $^{2}$

Sagt på en anden måde blev alt offentligt organiseret samvær, og samvær organiseret af markedet, opfattet negativt som henholdsvis formynderisk og styret af $\varnothing \mathrm{ko}-$ nomibestemte værdinormer.

Idrætsforeningerne blev et af flere menneskelige åndehuller (som eksempelvis venskabet og familien) i en følelsesforladt verden, hvor det enkelte individ kunne være sig selv.

\section{Nogle centrale forståelseskategorier $i$ idratsforeningernes selvforståelse}

Centralt i idrætsforeningerne stod tanken om, at det sociale fællesskab og samværet $i$ foreningen skulle være reguleret af emotionelle værdier. Derfor var den frivillige deltagelse, det uegennyttige engagement og kammeratskabet det, som gav idrætsforeningen værdi, både for idrætsforeningernes medlemmer, det offentlige og politikerne. Idrætsforeningen repræsenterede muligheden for et fællesskab, som var båret af oprigtige og egennyttige værdier, fri af marked og offentlig styring - dét var idealet, som man stræbte efter. ${ }^{3}$

Dette er et dybtliggende grundtræk, som beskriver den sammenhæng i idrætsforeningernes selvforståelse, som kan forventes at ligge bagved de beskrivelser og oplevelser, som konkret kan findes i kilderne.

Ifølge sagens natur er det ikke muligt at beskrive et fænomen som selvforståelse i sit fulde omfang, men nogle centrale forståelseskategorier skal nævnes for dermed at give et indblik i de vigtigste værdier: 
Frivillighed. Idrætsforeningernes virke blev forstået som båret af engagement og frivillighed, fri af markedets profitorientering og det offentliges formynderi.

»De unge vak fra gadehjфrnerne«. Idrætsforeningerne gav mulighed for socialt fællesskab og et værn mod normløshed og kriminalitet.

Idrattens autonomi. Idrætsforeningerne så sig selv som værende uden for det offentliges kontrol og indblanding.

Kammeratskab. I idrætsforeningerne opfattede man sig selv som venner og kammerater $i$ et socialt fællesskab båret af emotionelle værdier.

Disse værdier i idrætsforeningernes selvforståelse skabte et konstant spændingsfelt, både $\mathrm{i}$ forhold til det omgivende samfund, internt i foreningerne, men også for det enkelte medlem af idrætsforeningen. Værdierne var - og er - hele tiden til debat: Hvordan lader det sig gøre at forene konkurrence, elite og ulighed med fællesskab og kammeratskab? Statslige tiltag, som f.eks. Fritidsloven, satte frivilligheden på prøve: Kunne man være ægte engageret i idrætsforeningen, hvis man fik $1 \varnothing n$ for at være der? Der er utallige eksempler på disse konflikter, men idealet om det frivillige kammeratlige fællesskab var konstant.

På den her skitserede baggrund er det lettere at forstå og forklare, hvorfor idrætsforeningerne op gennem det 20. århundrede fik en (stadig stærkere) særposition i den kommunale - og for den sags skyld statslige - (velfærds)politik. Organiseringen af de sociale relationer i idrætsforeninger blev af menigmand såvel som administratorer og politikere opfattet som steder, hvor realiseringen af »det gode og rigtige liv« kunne forventes at udfolde sig. Det gode samvær i idrætsforeningerne kom til at fremstå som en næsten »tavs « civilisationskritik ved dets blotte tilstedeværelse. Idrætsforeningerne, og for den sags skyld idrætten som sådan, blev i denne proces forbundet med fremtiden og udfrielsen fra dagligdagens trædemølle; det var dér, livsglæde, spontanitet, ungdommelighed, vitalitet og venskab fandtes - så længe offentlig styring og markedskræfter blev holdt ude.

\section{Kammeratskab}

I det følgende skal der gives nogle eksempler på, hvordan forståelseskategorien kammeratskab i de tre kommuner København, Ballerup og Skive har indvirket og formet debatten internt $\mathrm{i}$ idrætsforeningerne og mellem idrætsforeningerne og kommunen.

Kildemæssigt anvendes hovedsageligt idrætsforeningernes medlemsblade, avisdebatter og kommunalbestyrelsernes forhandlingsprotokoller. Her skal det tages i betragtning, at netop idrætsforeningerne $\mathrm{i}$ deres medlemsblade foruden at henvende sig internt til medlemmerne næsten altid førte en underforstået dialog med de kommunale myndigheder om, hvor vigtig en samfundsopgave man udførte i idrætsforeningerne - lokalpolitikerne læste nemlig også foreningsblade. Derfor havde artiklerne ofte en meget positiv tone, hvor kritik af de gældende forhold sjældent slap igennem. Man ønskede ikke at lægge spalter til såkaldt brokkeri. ${ }^{4}$

Forståelsen af kammeratskabet kom ofte til udtryk i temaer, som udspillede sig igen og igen. 


\section{Tema 1. Den gode sportskammerat}

Hvis medlemmerne i Fremad Valby i 1940 var i tvivl om, hvordan en rigtig kammerat opførte sig, var der råd at hente i klubbens medlemsblad. Her kunne man læse »opskriften« på en god kammerat - og for en ordens skyld også et par eksempler på den modsatte type.

Den gode kammerat var ham, der kom for idrættens skyld, og som aldrig kværulerede over træningen eller andet. Han kom til tiden, og lod ikke andre stå og vente på sig. Desuden sendte han afbud i god tid.

Den dårlige kammerat opfattede sig selv som holdets »stjerne«, også kaldet »primadonnaen «. Han kom kun til kamp og træning, når det passede ham, og tog aldrig skylden for tabte kampe, men gav altid de andre på holdet skylden.

Et andet eksempel på en dårlig kammerat var »turisten «. Denne var ikke virkelig interesseret i idræt, men kun interesseret $\mathrm{i}$ at prale med at være medlem og mødte derfor aldrig til træning. ${ }^{5}$

Ikke overraskende var konklusionen, at kun den førstnævnte type var velkommen i klubben.

På lederplads kunne man i 1944 under overskriften: »Sejre og kammeratskab « lase, »at vi er en forening af gode kammerater, der $\phi$ nsker at tilbringe vor fritid $i$ såvel sportslig som venskabeligt samvar. ${ }^{6}$

Det var vigtigt, at de unge medlemmer fik lært, hvad en god kammerat var. I mange idrætsforeninger tog man ret håndfast på denne lektie. Et eksempel herpå findes $i$ »Sundbys 10 bud « der i 1943 blev bragt i medlemsbladet for Sundby Boldklub. Heri fik børnene $\mathrm{i}$ en blanding af gode råd (»mфd ren og ordentlig i tфjet«, »ordentlige knopper i stфvlerne«), og moralske formaninger (»spil aldrig råt og ubehersket«, »kvaruler aldrig over dommerens kendelser«) bl.a. at vide, hvordan en god kammerat opførte sig:

1. Skald aldrig din medspiller ud, men opmuntrer ham $i$ stedet for.

2. Var aldrig egoistisk $i$ dit spil, men husk der er 10 andre på banen.

3. Svigt aldrig dine kammerater ved at blive vak, husk at sende afbud. ${ }^{7}$

Der var ingen tvivl om, at det gode kammeratskab var på prøve, hver gang man spillede:

»Under kampen er der en kammerat, der jokker i spinaten, men du gaber ikke op og skalder ham ud for »dumme svin« og lignende vel, nej, du giver ham et opmuntrende tilråb og hjalper ham, hvis det er dig muligt, thi din sport har lart dig, at vi ikke alle er lige dygtige, og at vi ude i livet må respekteres af dem, der står på et lavere niveau, ligesåvel som vi фnsker at respekteres af dem, der står på et højere niveau end vi selv [...] Solidaritet og kammeratskab, to store faktorer såvel indenfor sporten som ude i livet ${ }^{8}{ }^{8}$

Samme tanker gjorde man sig i Ballerup Idræts Forening i 1947, hvor man i medlemsbladet spurgte: »Hvad forstås ved en god sportsmand?«, og svaret gav man selv: ${ }^{9}$ En god sportsmand måtte ikke blive til en sportsidiot, der stod for en fanatisk indstilling i modsætning til det sociale foreningsmedlem. Den gode sportsmand måtte heller ikke blive en »publikumsspiller, der blot фnsker at tage sig ud«. Man måtte heller ikke have et hidsigt temperament, der gav sig udslag i råben og skrigen eller endeløse diskussioner, når man mødte modgang. En sportsmand optrådte altid med et smil, »således at der $i$ forbindelse 
med udøvelsen af sporten kan blive oprettet et kammeratskab, der nemlig er af allerstørste vardi for en sportsforening «. ${ }^{10}$

Gennem hele artiklen lød moralen, at man som sportsmand ikke kun skulle tænke på sig selv, men være et socialt menneske, der også tog hensyn til andre. Hvis man var det, ville det gode kammeratskab opstå spontant, nærmest pr. automatik.

Den sociale optræden var en særdeles stærk faktor i opfattelsen af det gode sportskammeratskab.

I forhold til foreningen fik forståelsen af kammeratskabet ofte en etisk forpligtende dimension. Formanden for Ballerup Idræts Forening, Ove Bertram, mente således i 1950, at man først kunne kalde sig en rigtig sportskammerat, når man havde opfyldt sine forpligtelser over for sin klub og sine kammerater. ${ }^{11}$

Samtidigt med at kammeratskabet var en nødvendig del af klublivet, lå det i selvforståelsen, at kammeratskabet altid var i fare, og at det nærmest pr. definition var meget bedre og mere fasttømret $» i$ gamle dage «. Kammeratskabet trivedes bedst under lidt beskedne forhold, hvorimod for megen forkælelse og magelighed gjorde sammenholdet slapt. Henry Hansen fra Ballerup Idræts Forening fortalte i medlemsbladet om gamle dage i foreningen:

»... jeg husker endnu det gode kammeratskab, der herskede dengang. For at tage et eksempel, så kom en af spillerne ved navn Harald og sagde, at han desvarre ikke kunne komme om søndagen, da han skulle grave have efter farmands ordre. Der stillede straks det resterende hold med hver sin spade, og så blev haven hurtigt gravet, og Harald kom med om søndagen. Jeg ville фnske, der var noget af den ånd $i$ vor $k l u b \ll .{ }^{12}$
Hvad dette citat også løfter sløret for, er et kammeratskab, der hvilede på den nærhed og det kendskab til hinanden, lokalsamfundet gav mulighed for. Man boede ikke længere væk fra hinanden, end at man hurtigt kunne stille op med spader og grave.

\section{Tema 2. Kammeratskabet som forbillede}

I idrætsforeningernes fortællinger om sig selv fik kammeratskabet ofte en næsten mytologisk karakter. Igen og igen blev kammeratskabet i netop ens egen klub trukket frem som værende af en særlig god kvalitet. Et par eksempler:

\section{Kammeratskab og}

\section{flødeskumskager i Fremad Valby}

Ved Fremad Valbys 30-års jubilæum i 1934 bragte klubbens medlemsblad nogle erindringsartikler om klubbens første år. I disse artikler gengives nogle af de historier om klubbens stiftelse, som sikkert har været fortalt et utal af gange i omklædningsrum og klublokale efter træning. I dette tilfælde siger klubhistorien, at Fremad Valby blev stiftet i 1904 af seks drenge i 10-12-års-alderen, der boede i de samme boligblokke. I det første år var klubben nærmest en gymnastikforening med alle slags idrætsaktiviteter på programmet. Forholdene var yderst primitive. Gymnastik foregik i et stativ med ringe og en trapez, og en løbebane med grus måtte opgives, da det eneste transportmiddel var en trillebør. Man havde endda planer om at lave et svømmebassin i et vandhul. Virkelysten og visionerne var store.

Efter den stiftende generalforsamling, hvor der blev serveret chokolade og kager, blev det vedtaget at købe en brugt fodbold 
hos den rige naboklub Kjøbenhavns Boldklub. Så snart indkøbet rygtedes i boligblokkene, strømmede det til med drenge til klubben. ${ }^{13}$

Et par år senere led sammenholdet og kammeratskabet et alvorligt knæk, da spillerne en træningsaften blev uvenner, og en af spillerne $\mathrm{i}$ frustration skar fodbolden $\mathrm{i}$ stykker, og en anden begyndte at spise blæren (der var en svineblære). Resultatet blev, at de fleste spillere gik over i en ny boldklub med navnet Concordia.

Denne triste historie om kammeratskabets nederlag blev af artiklens forfatter alligevel en bekræftelse på styrken i de resterende syv-otte drenges sammenhold og kammeratskab:

»Samfolelsen mellem disse drenge var så stor, at de $i$ deres tro på klubbens fremtid uden undtagelse uge efter uge afleverede deres sammensparede $\phi r e r$ til en falles kasse, der, da den indsamlede sum var stor nok, blev anvendt til indkøbet af en ny fodbold «. ${ }^{14}$

Tilmed blev den rivaliserende klub, Concordia, nedlagt, fordi bestyrelsen brugte alle klubbens penge til flødeskumskager.

For artiklernes forfattere rummede disse anekdoter et budskab om den særlige sammenholdsfølelse, som gennem tiderne havde båret Fremad Valby gennem svære tider. Det er historien om gadedrengene, der i kraft af deres sammenhold og kammeratskab får skabt en levedygtig boldklub. For selvforståelsen i Fremad Valby var kammeratskabet grundstenen i foreningens særlige klubånd.

Dette eksempel genfindes i mange variationer i de fleste idrætsforeninger. Gennemgående for alle fortællingerne er, at sammenholdet og kammeratskabet i den pågældende forening er unikt.
I næsten alle idrætsforeninger uddelte foreningen ved den årlige afslutningsfest såkaldte kammeratskabs- og spillerpokaler til medlemmer, der med deres opførsel havde gjort sig særligt bemærket. I Ballerup Idræts Forening havde man en ungdomspokal, der blev uddelt med følgende begrundelse:

»Pokalen skal tildeles et medlem, der foruden at vare en god fodboldspiller, tillige skal vare en god kammerat. Hans opforsel såvel $i$ foreningen som privat skal kunne danne forbillede for andre. Han skal vare flink og villig såvel i foreningen som i skole eller på arbejdsplads, og han skal altid reprcesentere Ballerup Idrats Forening på en vardig måde «. ${ }^{15}$

Netop fordi idrætsforeningen opfattede det gode kammeratskab som et særkende for idrætten, var det af stor betydning, at de unge idrætsfolk også i det omgivende samfund kunne repræsentere de værdier, idrætsforeningen stod for. Skoler og arbejdspladser skulle på den måde, et ungt menneske opførte sig, kunne se, om vedkommende var medlem af en idrætsforening.

\section{Tema 3. Kammeratskabet $i$ krise}

Medlemmerne havde en stærk forventning om, at man i idrætsforeningen på det venskabelige plan var ligeværdige. Men i praksis - i idrætsforeningens hverdag blev denne forestilling ofte udfordret. Ethvert tilløb til uro i kammeratskabet var farligt for medlemmernes engagement. Man var netop frivillig leder, fordi man i idrætsforeningen kunne forvente at møde et fællesskab båret af venskabelige følelser. 
»Er der gået møl i sammenholdet? « - problemer i Fremad Valby

I en artikel i Fremad Valbys medlemsblad i 1936 med overskriften: »Hvor er det gode kammeratskab? Er der gået møl $i$ sammenholdet? «, var klubbens formand, Otto Olsen, ude med en hård kritik af medlemmerne i klubben. Især var fremmødet til kampe og træning et stort problem, hvorfor han fandt det nødvendigt at beskylde medlemmerne for at være dårlige kammerater, hvilket i klubbens selvforståelse var noget af det værste, man kunne blive kaldt. ${ }^{16}$

Også hos Maaløv Boldklub var et skrantende kammeratskab et tilbagevendende problem op gennem 1950'erne. Det kom bl.a. til udtryk ved, at de aktive medlemmer ikke bakkede nok op om klubbens arrangementer. Dette fik formanden til i sin beretning i 1959 at skælde ud på det dårlige kammeratskab:

»Det er det enkelte medlems indstilling overfor kammeraterne og overfor klubben, der er forkert; man går til trcening, stcevner og kampe, men passer sig selv for og efter; man prøver ikke at få kontakt med bl.a. nye medlemmer ... man vil simpelthen ikke gøre klubben til en stor kammeratlig enhed, et sted hvor alle er lige og alle er ens, et sted med kammeratskab og et godt sammenhold $\ll{ }^{17}$

På trods af alle de pæne ord og intentioner om et godt kammeratskab var det ikke alle idrætsforeningernes medlemmer, der havde gode erfaringer i den forbindelse, især ikke hvis man tilhørte klubbens mindre dygtige idrætsfolk. Det var sjældent, at nogle af disse idrætsfolk udtrykte deres frustration i medlemsbladene, men et eksempel kan findes i medlemsbladet for Fremad Valby i 1949:
»Undertegnede f.eks. hører til de såkaldte "fuser" inden for klubben. Det som mange udtrykker som "fyld«, men fyldet har også sin berettigelse her $i$ verden. Vi betaler vort kontingent ligesåvel som de andre, vi er mindre fordringsfulde end de såkaldte »Stjerner " som følge af vore spillemassige ydelser. Men hvorfor skal vi behandles anderledes af ledelsen og kammeraterne? ... kunne man toenke sig at 1. holdet skulle stå en søndag eftermiddag $\mathrm{kl} .13 .30$ på Islands Brygge, uden at der var sørget for trøjer til dem, og eventuelt tabe en kamp, grundet på mangelfuld påklaedning? Na, det

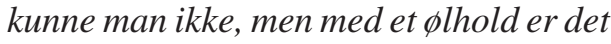
lige meget, det er noget helt andet. ... Så til slut lidt om traningen, som jeg mener er forkert tilrettelagt af ledelsen.

Den foregår på den sadvanlige måde: med dem, der spiller godt, for sig, med den bedste bold samt traneren, Derefter "fuserne" rendende rundt og fjolle med en »melon ««. ${ }^{18}$

At denne type indlæg i idrætsforeningernes medlemsblade var sjældne, kan ikke nødvendigvis tages som udtryk for, at det beskrevne problem ikke var sjældent forekommende. Medlemmer som Arne Glud, som bare var »fyld «, var sikkert tilbageholdende med åbenlyst at kritisere forholdene, da man i idrætsforeningens selvforståelse som sportsmand helst skulle udtrykke glæde, vitalitet og positivitet. Derfor ser man ofte, at denne type indlæg blev ledsaget af udglattende kommentarer om, at man ikke $\emptyset$ nskede at være sur, negativ eller kværulantisk.

\section{Hvem skal med på rejse?}

Sportsrejserne blev efter afslutningen på 2 . Verdenskrig en stadig vigtigere del af 
idrætsforeningernes aktiviteter. Før 1945 gik rejserne hovedsageligt rundt i det danske land, men i takt med den generelle velstandsstigning og åbning mod verden uden for Danmark blev udlandet et stadigt hyppigere mål. En vigtig funktion ved rejserne var styrkelsen af kammeratskabet. På trods af det ganske store arbejde, organiseringen af rejserne indebar, var disse rejser uhyre populære både blandt medlemmer og ledere - ikke mindst fordi de var billige.

Men netop fordi det var så attråværdigt at komme ud og rejse, var hele udvælgelsesproceduren til rejserne ofte udsat for stærk kritik og satte det gode kammeratskab på en hård prøve. Hvem var indenfor i den kammeratlige varme, og hvem var udenfor?

En konflikt opstod eksempelvis, da Ballerup Idræts Forening skulle på en rejse til Sverige i 1950. I medlemsbladet kommenterede en af klubbens fodboldspillere hele forløbet op til rejsen således:

»Som sekundaspiller tillader jeg mig at spørge ledelsen: efter hvilken fremgangsmåde bliver de spillere udvalgt, derf.eks. rejser til Sverige og spiller fodbold? I forste omgang prøver jeg selv at svare. Jo, vi skal jo have klubbens stcerkeste hold af sted, man kan jo ikke vare bekendt at komme osv. osv. ... i stedet bliver der sludret lidt, og så finder man et par enkelte stykker frem fra henholdsvis 2. og 3. holdet, og når så ledelsen ydermere har taget nogen af deres bekendte med til de sidste pladser, ja så har vi et reprasentativt hold med reserver!! $\ll^{19}$

Bag denne kommentar gemte sig formentlig problemer med klikedannelser, og at nogle var mere kammerater end andre.
Tema 4. Når kammeratskabet står $i$ vejen for medlemsdemokrati og debat

Det skete også, at kammeratskabet stod i vejen for den frie debat i idrætsforeningerne. Den positive oplevelse af, at kammeratskabet skabte en intim samværsform, kunne vende til en negativ oplevelse, når kammeratskabet blev for intimt og fik karakter af et lukket broderskab. Da kunne det blive et problem frit at sige sin mening. Kritik af eksisterende forhold blev nu opfattet som et brud på det kammeratlige sammenhold. I Ballerup Idræts Forening kom dette problem bl.a. til udtryk i 1950, hvor bestyrelsesmedlem Paul Lund i medlemsbladet gjorde sig nogle tanker om demokrati og kammeratskab. Baggrunden var, at der i bladet havde været en del indlæg under pseudonym, hvilket af mange medlemmer var blevet tolket, som at man ikke turde være sit indlæg bekendt. Herom skrev Paul Lund:

$\gg$ Men jeg tror grunden er en helt anden, og her rorer vi ved det gamle fortarskede emne kammeratskabet.

»Ja, men vil du da påstå, at der ikke eksisterer kammeratskab i foreningen, " vil nogen spørge.

Jo, men er vi $i$ besiddelse af den fornodne tolerance til at høre på en kammerats mening, enten den er rigtig eller forkert.

Er den rigtig, vil vi da tage ved lare af den, og er den forkert, er vi da så meget kammerater, at vi roligt og sagligt vil forklare ham eller hende, hvorfor han eventuelt har uret $i$ sine synspunkter, eller afviser vi ham uden diskussion med skuldertrak, der siger det samme som: »du er jo ikke rigtig klog." 
Og er vedkommende lige vellidt $i$ sin afdeling, selv om han stadig forfagter den mening, han ikke fra anden har fået modbevist.

Desvarre er denne tolerance ikke altid tilstede, og jeg tror det er dette forhold der afholder vore medlemmer fra at sige deres mening på generalforsamlingerne, eller udtrykke sig gennem vort eget organ Ballerup-Sport «. ${ }^{20}$

Her afslørede Paul Lund, at kammeratskabet i Ballerup Idræts Forening også havde en undertrykkende virkning. Hvis et medlem fremførte et kritisk synspunkt, der gik på tværs af de underforståede normer, risikerede vedkommende i praksis en eksklusion fra kammeratskabet.

Når et bestyrelsesmedlem som Paul Lund i medlemsbladet luftede sådanne tanker om kammeratskabets beskaffenhed, var det sandsynligvis udtryk for nogle større underliggende konflikter vedrørende klikedannelser i foreningen.

Problemet fortsatte åbenbart, for i 1951 kunne man i Ballerup-Sport læse om, hvordan visse personer blev beskyttet af deres klike. ${ }^{21}$ Og i 1952 kunne man læse om, hvordan nogle af fodboldafdelingens medlemmer på egen hånd havde arrangeret en venskabstur til venskabsklubben i Østrig uden om hovedbestyrelsen og dermed omgået de sædvanlige åbne udvælgelseskriterier for deltagelse i udlandsrejser. ${ }^{22}$

For meget øldrikkeri kunne også være en trussel mod kammeratskabet. Dette måtte Vanløse Idrætsforening sande i 1958.

Sagen - hvis enkeltheder fortaber sig i det dunkle - handlede om, at bestyrelsen havde forbudt alkohol i klublokalet. Samtidigt havde restauratøren i Vanløse Idrætspark (hvor klublokalet lå), som var ansat af Københavns Idrætspark, ret til udskænkning af spiritus, hvilket bl.a. betød, at der i restauratørens skur kunne købes og drikkes $\emptyset 1$. Sagen udviklede sig så meget, at næstformand Haakon Knudsen måtte forlade klubben på grund af chikane. Han modtog anonyme skrivelser, og hans bil blev gennemtisset og spyttet på, når den var parkeret ved klublokalerne. ${ }^{23}$

Hele sagen blev bragt og kommenteret $\mathrm{i}$ Ekstra Bladet. Journalisten fra Ekstra Bladet mente, at Københavns Idrætspark skulle gå ind i sagen og støtte ølforbuddet, ikke mindst fordi det var et dårligt eksempel for den ungdom, der kom i klubben, og man appellerede til VIF's fornuftige mennesker, at de skulle fjerne kliken med $\varnothing$ llerne. ${ }^{24}$

Ifølge Ekstra Bladet fordømte bestyrelsen i VIF »den gadedrengeagtige opførelse« fra en gruppe mennesker i foreningen. ${ }^{25}$ I første omgang var det ikke så meget selve sagen, som chokerede klubbens formand, E. Sonne, men snarere at sagen var lækket til pressen. I en lang artikel i klubbens medlemsblad beklagede han hele hændelsesforløbet:

»I forste omgang virker det chokerende - ikke så meget på grund af artiklens indhold, vel noermest fordi det går enhver rigtig VIF'er til hjertet, at se sin klub»hoengt ud« offentligt. For lad artiklen vare nok så rigtig - dermed vare ikke sagt, at den er det på alle punkterså havde vi vist alle varet bedre tilpas uden artiklens offentlige fremkomst $\ll .{ }^{26}$

På mange måder var denne reaktion typisk for idrætsforeningerne. Man ønskede ikke »det beskidte vasket $\varnothing j \ll$ offentligt udstillet. $^{27}$

E. Sonne kunne ikke tilbagevise de oplysninger, som Ekstra Bladet bragte, hvorfor han satte megen energi ind på at finde den skyldige, som var gået til pressen: »Er der tale om en hovnakt? «28. I den anled- 
ning havde bestyrelsen fors $\emptyset$ gt at finde frem til ophavsmanden - der formastede sig til at forlange, at bestyrelsen tog klar stilling til spørgsmålet om $\varnothing$ ldrikkeriet.

Københavns Idræts-Forening oplevede i 1970 den for en idrætsforening næsten værste situation, nemlig at få interne stridigheder udleveret i pressen. Offentligg $\varnothing$ relsen af konflikten var netop et brud med billedet af den gode kammeratlige forening. En krise, der mere bundede i uenigheder om samværet $\mathrm{i}$ foreningen end sportslige spørgsmål, fik nogle medlemmer til at melde sig ud af foreningen og ind $i$ en anden. I dagspressen blev bestyrelsen i Københavns Idræts-Forening af afhopperne kaldt for diktatorisk, fascistisk og rethaverisk og beskyldt for ikke at lade kritiske medlemmer komme til orde. Til gengæld kaldte bestyrelsen afhopperne $»$ forrcedere, som havde svigtet deres kammerater«. I foreningens medlemsblad kunne man læse følgende reaktion på konflikten:

»... hvis vi vil undgå de for Kфbenhavns Idrcets-Forening tilspidsede situationer, som dem vi oplever nu, må vi - også $i$ bladet - give også »negative og udemokratiske" opionsytringer lov til at komme til orde. Men lad dem ikke stå uimodsagt! $\ll^{29}$

Under denne tilsyneladende positive holdning om at lade forskellige meninger komme til orde i medlemsbladet, gemmer sig imidlertid en mere restriktiv praksis. Denne praksis blev af redaktionen selv på bladet ikke oplevet som en bevidst censur mod kritik, men derimod en reaktion mod ytringer, der brød med den kække, positive og glade tone, man mente hørte sig til i en idrætsforening. Meninger, der udtrykte sig negativt og påstod, at idrætsforeningen var udemokratisk, kunne man i denne selvfor- ståelse ikke tage alvorligt, for en idrætsforening var pr. definition selve indbegrebet af positiv og demokratisk adfærd. På den måde blev idrætsforeningen hævet over meninger og holdninger, der sagde det modsatte, og alle ytringer, der vendte sig mod foreningen, var også pr. definition udemokratiske og negative.

\section{Tema 5. Intet klubhus, intet kammeratskab}

Skulle et kammeratskab kunne trives, var det nødvendigt med et klublokale, hvor medlemmerne kunne mødes uden for træning og kamp. For mange idrætsforeninger var det derfor et stort problem, hvis et sådant klublokale ikke fandtes eller var $\mathrm{i}$ en meget dårlig stand.

Da det nye stadion i Skive blev indviet i 1944, var det vigtigt for Skive Idræts Klub, at det gamle røde klubhus fulgte med. ${ }^{30}$ Flytningen kan tolkes som udtryk for, at identiteten skulle med til den nye adresse, fordi klubhuset for Skive Idræts Klub var et symbol på kammeratskab og fællesskab.

Megen af foreningernes energi gik med at arbejde for et klubhus. Ballerup Idræts Forening oplevede det efter 1945 som et stigende problem, at klubbens medlemstal voksede kraftigt, og nye afdelinger kom til. På den ene side havde foreningen som mål, at der skulle være plads til alle i foreningen, og på den anden side skabte dette mål problemer for kvaliteten af det sociale samvær, for hvor skulle de mange medlemmer dyrke samværet, når træningen var forbi?

Hvem, der skulle opføre og betale for klubhusene, blev efter 1945 et spørgsmål, der stadig oftere kom på dagsordenen i forhandlingerne mellem idrætsforeningerne og kommunen. For Ove Bertram var der 
ingen tvivl: i en artikel i 1949 argumenterede han for, at anlæggelse af idrætsanlæg var en kommunal opgave, mens det var idrætsfolkenes opgave at stå for den gratis ledelse i idrætsforeningerne. Med 1930'ernes beskæftigelsesarbejder, der stoppede $\mathrm{i}$ 1945, blev der ganske vist opført mange idrætsanlæg for statens penge, men det blev også en »sovepude« for kommunerne. Idrætsanlæg blev kun opført, når der var arbejdsløshed.

Derfor lå mange anlæg ufuldendte hen, ligesom Boligministeriets forbud mod anvendelse af byggematerialer havde bremset byggeriet af idrætshaller. Ove Bertram mente, ligesom flertallet af de frivillige idrætsledere, at et krav til kommunen om $\emptyset$ konomisk støtte forudsatte en stærk indre moral hos idrætsforeningerne. Først når medlemmer og ledere i idrætsforeningerne opførte sig ansvarligt over for hinanden og foreningen, havde de den moralske ret til at forlange noget af de kommunale myndigheder.

Videre i artiklen beklagede Ove Bertram sig over, at det ikke var muligt at skabe en mere intim kontakt mellem de enkelte afdelinger i idrætsforeningen. Årsagen hertil skulle igen - ifølge Ove Bertram findes i det manglende klubhus. Hvis muligheden for samvær var til stede, ville kendskabet til hinanden på tværs af idrætsgrenene blive meget bedre.

Da repræsentanter fra Ballerup Idræts Forening i 1950 besøgte Herlev Idrætsforening, havde de svært ved at skjule deres misundelse over Herlevs idrætsfaciliteter. Ikke mindst fordi disse idrætsfaciliteter skabte gode rammer for at stifte »et godt kammeratskab«, fandt delegationen fra Ballerup Idræts Forening, at sognerådet havde »en forpligtelse overfor disse mennesker ${ }^{31}$
Her bliver kammeratskabet forstået som en vigtig faktor i borgernes velfærd, som der politisk burde tages hånd om.

Klublokalerne blev udstyret med vundne pokaler og fotografier fra fælles oplevelser. I klublokalet kunne man dyrke klubånden og det uformelle samvær. Man spillede kort, fortalte historier, drak $\emptyset \mathrm{l} \mathrm{og}$ sodavand samt pjattede og drillede hinanden. Da Skive Idræts Klub i 1966 fik et nyt klubhus, var Skive Folkeblad meget benovet over de moderne forhold:

»Det eneste man synes at mangle, er en opholdsstue, hvor ledere og idratsfolk kan samles til en snak efter traningen. Ellers er der alt hvad der skal vare: der er fem omkladningsrum, og et specielt dommervarelse med bad og toilet. Endvidere er der tre baderum med $i$ alt 18 brusere. I det gamle klubhus var der to ...! Endelig er der $i$ den vestlige ende indrettet redskabs-og fyrerum samt toiletter ${ }^{32}$

Alt syntes at være $\mathrm{i}$ orden, lige udtagen de fysiske rammer for, at det kammeratlige samvær kunne blomstre - et klublokale.

Skive Dameroklubs formand gjorde i klubbens første leveår noget ved dette forhold. I en jubilæumsartikel i Skive Folkeblad i 1966 fortæller klubbens daværende formand herom:

»Hun byggede egenhandigt foreningens opholdstue, som foreningens medlemmer har haft stor glode af og som har medvirket til at skabe det gode kammeratskab, der altid har hersket $i$ Dameroklubben. Opholdsstuen, hvori der er blevet drukket i spandevis af kaffe, blev indviet $i$ 1952 «. ${ }^{33}$ 
Her bliver to symboler på samvær og intimitet sammenknyttet, nemlig stuen og kaffen.

I 1979 fejrede Fremad Valby atter et jubilæum. I medlemsbladet fortsatte formanden, Eli Pedersen, den næsten rituelle lovprisning af kammeratskabet, og han udtrykte også et $\varnothing$ nske:

»Et af de store фnsker og mål, vi håber at kunne nå indenfor de narmeste år er, at få eget klubhus - et klubhus, der skal danne rammen om medlemmerne trivsel og farden, et sted, samhørighedsfølelsen kan gro for unge og aldre, aktive som passive, Et varested, der i kammeratskabets ånd skal gøre vores klub stark ${ }^{34}$

På mange måder opfattede man det ideelle klubhus som et hjem, hvor familien (klubben) kunne trives.

\section{Tema 6. Kammeratskab og penge}

For de store fodboldklubber i København som f.eks. AB, B93 og KB betød de mange tilskuere til 1. divisionskampene i begyndelsen af 1950'erne, at der blev tjent rigtig mange penge. Indtægterne var selvfølgelig kærkomne for klubberne, men de var også en udfordring til det kammeratskab, der var så vigtigt i deres selvforståelse. Konflikten mellem på den ene side hensynet til indtægterne og på den anden side vedligeholdelsen af kammeratskabet var imidlertid ikke kun isoleret til fodboldklubberne, men blev også diskuteret i de øvrige idrætsforeninger.

For Københavns Idræts-Forening blev pengenes negative betydning for kammeratskabet demonstreret ved en episode $\mathrm{i}$
1954 i forbindelse med en divisionskamp i fodbold. I foreningens medlemsblad kunne man læse en hård kritik af fodboldspillet. Baggrunden var, at en fodboldspiller fra B93 efter at have kikset et straffespark blev hængt ud i aviserne. Dette fik Københavns Idræts-Forening til at beskylde aviserne for en hysterisk dækning af sport - og i særdeleshed fodbold - der ikke levnede plads til at omtale atletik:

"Hvor er vi henne - det er foreningernes pengekasser der spilles for, mere end for spillernes fornøjelse. Kammeratskabsf $\phi$ lelserne går fløjten. En ny og måske talentfuld spiller, der nu mere end nogensinde tranger til kammeraternes stotte, bliver vist vaek og fär skylden for at have givet foreningen et tab på tusinder af kroner...

Lad os så hellere blive ved med at vare en upåagtet idrcetsgren, hvor det er lysten der driver varket $\ll .{ }^{35}$

Det kammeratlige samvær i idrætsforeningerne blev oplevet som udsat for fare fra pengenes - eller markedets - indflydelse. Derfor kunne eksemplet med B93 bruges som et skræmmebillede på, hvor galt det kunne gå, hvis man lod afhængigheden af indtægter styre samværet $\mathrm{i}$ foreningen. Samtidigt var eksemplet også et bevis på, at man i en idrætsforening som Københavns Idræts-Forening havde det rette kammeratskab. For hvis man ikke var afhængig af entréindtægter, havde kammeratskabet også de sundeste vilkår at fungere under.

For Knud Lundberg, der spillede fodbold for $\mathrm{AB}$, og som var en af datidens mest feterede fodboldspillere, var der ikke nødvendigvis nogen modsætning mellem kammeratskab og penge. I sin erindringsbog Et liv i leg ${ }^{36}$ beskriver han på en meget morsom måde datidens opfattelse af, hvor- 
dan amatørisme, penge og kammeratskab var forbundet med hinanden:

»Vi var amatфrer. Og overbeviste. Vi blev skrupforargede, når vi hфrte, at $\emptyset B$ 'erne [Østerbro Boldklub, red.] fik hundrede kroner hver aften for deres kampe på Idratsparken. Som de kunne gå ud og spise og drikke for.

Allermest forargede blev vi, når Carl Aage Prast tog pengene med hjem til Lizi, i stedet for at gå ud og drikke dem op. Det var jo den rene, skinbarlige professionalisme!

Vi andre blev såmond lige så godt betalt, men på en anden måde. Som amatører. Vi og vores piger blev inviteret til middag nasten hver sфndag efter vores kampe på Idratsparken. På et af byens fineste spisesteder. Det kostede nok klubben lige så meget som de 100 kroner, som hver ØB'er fik, men det var altså anerkendt. Som god amatфrskik.

Forskellen var den, at vi holdt sammen på holdet, at vi drak sammen i stedet for i smågrupper $\ll .{ }^{37}$

Hvis pengene, man modtog, blev anvendt sammen med holdkammeraterne $\mathrm{i}$ et venskabeligt samvær, var der ingen problemer med at leve op til idealet om det gode kammeratskab. Man kan sige, at eksistensen af kammeratskabet blev opfattet som det sikre værn mod pengenes fordærvende virkning.

\section{Tema 7. »Os og de andre«}

Kammeratskabet blev ofte defineret som en modsætning eller negation af »de andre«, og ikke sjældent havde man en såkaldt fjendeklub, som »man i hvert fald var meget bedre end «. Kammeratskabet og den identitet, som var knyttet dertil, var altså bestemt af to relationer: 1) internt (ved det emotionelle) og 2) eksternt (ved afgrænsning til de andre idrætsforeninger).

Da Arbejdernes Idræts Forening og Skive Idræts Klub blev sammensluttet den 19. september 1964, var man i begge foreninger meget bekymrede for, om man ville kunne komme overens. Baggrunden var nemlig, at de to idrætsforeningers fodboldspillere i en årrække havde været hinandens »arvefjender «, og at man $\mathrm{i}$ årevis havde bekriget hinanden. Derfor måtte ledelsen i Skive Idræts Klub anvende medlemsbladet Frispark til en appel til klubbens medlemmer:

»AIF'erne er ikke fjender, der har overgivet sig betingelsesløst, det er Venner, der vil et samarbejde med os, og vore "gamle" medlemmer vilde vare meget dårlige sportsfolk, hvis de ikke sфrger for, at vore nye kammerater kommer til at fole sig hjemme indenfor Skive Idrats Klub. Sagt med andre ord: nu skal gammelt nag vare glemt $« .{ }^{38}$

Det er som nationer, der har været i krig, dog er forsoningen i dette tilfælde fredelig, for den består i at opføre sig som gode sportsfolk, for den gode sportsmand er nemlig en god kammerat.

For en folkelig idrætsforening som Ballerup Gymnastikforening, der i 1952 netop havde overstået et voldsomt opgør med Ballerup Idræts Forening, var spørgsmålet om fællesskab og konkurrence af særlig betydning. Ved flere lejligheder dukkede dette spørgsmål op i medlemsbladet. Facaden af enighed krakelerede f.eks. i 1952, da der opstod uenigheder og skænderier på herrehåndboldholdet. Årsagen var her, at holdet pga. af konkurrence mellem spillerne ikke kunne opretholde en ordentlig tone. ${ }^{39}$ 
De moralske opsange kom gerne i forbindelse med nytåret, som f.eks. i 1953 hvor der i medlemsbladets nytårshilsen stod:

»Det skal vare sådan, at idratten er jeres bedste kammerat, og en kammerat svigter man ikke, fordi det regner eller sner, eller fordi der går noget godt i biografen ... Et rigtigt godt 1953 фnskes alle gymnaster og kammerater ${ }^{40}{ }^{40}$

Her blev idrætsudøverens relation til selve idrætten på det nærmeste inderlig-og personliggjort. Idrætten skal man have et moralsk forpligtende forhold til, på samme måde som man har det til en nær ven.

I Ballerup Gymnastikforening mente man - ikke overraskende - at konkurrencesporten havde et grundlæggende problem i forhold til det ægte kammeratskab. I nytårshilsenen 1955 stod der i medlemsbladet: »I gymnastikken er det let at vare en god kammerat, for der er ikke den konkurrence, som melder sig på boldbanen «. ${ }^{41}$ På denne måde fik Ballerup Gymnastikforening indirekte sagt, at udøverne af den folkelige gymnastik var på et højere moralsk stade end de DIF-organiserede idrætsforeninger som f.eks. Ballerup Idræts Forening.

\section{Tema 8. Kammeratskab og lokalpolitik}

I 1944 blev Skive Stadion indviet to gange. Den første indvielse var til ære for Skive Idræts Klub og den anden for AIF (Arbejdernes Idrætsklub). Længere tids uoverensstemmelse mellem de to klubber var årsagen. Begge gange måtte borgmester Woldhardt Madsen og de $\varnothing$ vrige prominente gæster holde indvielsestale, og begge gange refererede aviserne trofast fra begivenheden. ${ }^{42}$
Ved SIK's indvielse af Skive Stadion var kammeratskabets værdi et hovedtema i næsten alle talerne. Formanden for Jydsk Atletik Forbund, Børge Linøe fra Århus, sagde f.eks.:

»Forhåbentlig vil byens ungdom forstå at vardsatte den gave, den her har fäet. Den vil kunne opleve rige glader her, og den vil opleve det sande kammeratskab. Kammeratskabet er nemlig det fundamentale $i$ al idratsarbejde ${ }^{43}$

Børge Linøe mente, at det sande kammeratskab fandtes i idrætten, og gaven fra kommunen var med andre ord muligheden for et socialt samvær båret af oprigtige værdier, følelse og lyst til at være sammen. Idrætspladsen repræsenterede muligheden for at færdes i et socialt miljø, hvor oprigtige og ægte relationer mellem individerne var til stede. 13 dage senere, ved AIF's indvielse, gentog borgmester Woldhardt Madsen i sin tale samme tema:

»Men under alle forhold må han erindre, at den adle sport har en uskreven lov, som ikke kan omgås, nemlig kammeratskabets lov. Uden den kan sund sport ikke udфves. Råhed i spil og ukammeratlig optrceden kan aldrig komme ind under begrebet sport, og den, som bruger disse tricks, har ingen ret til at kalde sig sportsmand ${ }^{44}$

God moral og kammeratskab sættes her sammen, ukammeratlig optræden er således lig med dårlig moral, og kun et menneske med en god moral kan kalde sig sportsmand. En sportsmand er altså lig med en person med en høj moral, der tilhører et særligt fællesskab - det sportslige fællesskab. 
Kommunalpolitikerne i Københavns Borgerrepræsentation lod ofte deres private syn på idræt skinne igennem de mere rent politiske diskussioner om sundhed og idræt. Når det skete, var det som regel ved at fremhæve det særlige kammeratskab, man mente fandtes i idrætsforeningerne.

Under en diskussion i 1964, hvor et udvalg til forbedring af forholdene for den københavnske idræt skulle nedsættes, ${ }^{45}$ begyndte politikerne et stykke inde i debatten at give udtryk for deres opfattelses af, hvad idræt skulle gøre godt for. Mens spørgsmål om bevillinger var præget af partipolitiske diskussioner, har den $\varnothing$ vrige diskussion mere præg af politikernes private tanker om idrætsforeninger. F.eks. sagde B. $\mathrm{Schmidt}^{46}$ fra Socialdemokratiet og medlem af Københavns Idrætspark:

»Må jeg sige til hr. L. Hansen, der peger på betydningen af, at mange kunne placere sig f.eks. ved de olympiske lege og sådanne store internationale stavner, som vi hører $i$ nogle forfordelige skrål $i$ radio og fjernsyn fra for tiden, at jeg hellere ser storre bredde i idrctten, end at jeg ser at man fremmer konkurrenceidrcetten på den måde. Det, at mange flere ville kunne lare at svømme og på den måde nyde fritiden satter jeg helt anderledes streg under, og jeg ved at kammeratskabet, det vare sig i atletikforeningen eller fodboldklubber og andet, betyder meget ved siden af selve den idrat, man så i фvvrigt driver «. ${ }^{47}$

Citatet rummer flere vigtige udsagn om, hvordan idrætten i København blev opfattet af lokalpolitikerne. Den almindelige befolknings muligheder for at dyrke idræt var vigtigere og mere værd end eliten, og idrætten skulle være en del af et større velfærdstilbud til alle borgere. I denne sammenhæng opfattede man det kammeratlige samvær i idrætsforeningerne som værende af meget stor værdi. Her er det interessant, at Børge Schmidt talte ud fra en personlig erfaring: »... jeg ved at kammeratskabet, det vare sig $i$ atletikforeningen eller fodboldklubber og andet, betyder meget ved siden af selve den idrat, man så $i$ $\phi$ vrigt skriver «. Det gode kammeratskab var den moralske rygrad i den velfærdsorienterede foreningsidræt.

Næsten samme holdning kom til udtryk, da idrætsprognosen i 1969 for København blev behandlet i borgerrepræsentationen. Til redegørelsen sagde Gunnar Ulbæk fra Socialdemokratiet:

»Hvor er det dejligt $i$ en tid, hvor man nasten dagligt kan laese om en ungdom, der kun lever med $i$ alt det negative. Intet er mere fejlagtigt. Aften efter aftensommer og vinter - samles den københavnske ungdom til traning og dygtiggørelse, afvekslende med venskabelige idratsopg $\phi$ r.

Enhver, der blot har en smule kendskab til ånden $i$ en idratsforening, ved, hvilken kolossal betydning kammeratskabet, faellesskabet og ansvaret har for modningen af et ungt menneske. Derfor kan Kobenhavns Boldklubs motto: »Tab og vind med samme sind «også stå som bomorke for den Kobenhavnske ungdom ${ }^{4}{ }^{48}$

Her sættes kammeratskabet ind i et socialpolitisk perspektiv rettet mod ungdommen. Udtalelsen bygger på en indforståethed blandt politikerne om, hvad der karakteriserer en idrætsforening. »Ånden i idrætsforeningen « er nemlig gennemsyret af venskabelige og kammeratlige følelser $i$ et fællesskab, der også er baseret på ansvarlighed for selvsamme værdier. 
Indførelsen af Fritidsloven udfordrede på mange måder idrætsforeningernes værdigrundlag. Kammeratskabet var ingen undtagelse, og både idrætsledere og politikere var bekymrede af denne grund. Det Konservative Folkeparti i Ballerup talte måske for de fleste byrådsmedlemmer, da partiet udtalte, at loven kunne risikere at $\varnothing$ delægge idrætsforeningernes indre sociale liv. Spørgsmålet var, om kammeratskab og samhørighed i idrætsforeningerne kunne overleve den løse tilknytning, som man kunne frygte, interessegrupperne ville få til foreningerne. ${ }^{49}$

I februar 1972 var Knud Pedersen, der i mange år havde skrevet om idræt og politik, blevet formand for Det Konservative Folkepartis vælgerforening i Ballerup Kommune. I den anledning skrev han en artikel i $C^{\prime}$ 'et om netop idræt og politik. Han mente, at idrætsledernes utilfredshed med mangel på træningsplads var helt berettiget, især når det blev taget $\mathrm{i}$ betragtning, at idrætten var den største fritidsbeskæftigelse for unge i Ballerup Kommune. For ham rummede idrætten langt mere end bare træningssteder alene:

"Livet i idratsklubberne er, og skal også vare, andet og mere end blot fysisk udfoldelse. Der skal vare klublokaler, hvor det kammeratlige samvar kan trives, og hvor man kan diskutere andet og mere end lige pointstillinger efter sidste spilledag eller sidste konkurrence $\ll .{ }^{50}$

Politikeren Knud Pedersen var således helt på bølgelængde med kommunens idrætsledere i opfattelsen af et klublokales betydning for samvær og kammeratskab.

Samme år - i maj-nummeret - tog Knud Pedersen atter spørgsmålet om foreningens brug af skolernes faciliteter op. Kommunen var bagefter med et skolebyg- geri, og da det sidste, som blev bygget, altid var gymnastiksalen, var idrætten hårdt trængt.

»Det er også - og måske endda først og fremmet - kammeratskab og sammenholdet om klubben. Skal dette kammeratskab og sammenhold trives, så kraver det noget at trives $i$, og dette er velegnede klublokaler, hvor der ikke, som på skolerne, pibes afgang på bestemte klokkeslcet ${ }^{51}$

Selvom der blev bygget haller ved skolerne, var dette ikke i sig selv godt for foreningerne, birum og klublokaler manglede stadig. Men vigtigst af alt var klublokaler, hvor det emotionelle fællesskab kunne blomstre uden formynderisk indblanding fra det offentlige, her symboliseret ved skoleklokken.

\section{Politisk indflydelse ad kammeratskabets vej}

Spørgsmålet er så, om denne fælles underforståethed og mentalitet vedrørende partipolitik og idræt fuldstændig udelukkede, at man i idrætsforeningerne søgte politisk indflydelse i sogneråd og kommunalbestyrelser - eller politisk indflydelse i det hele taget. Hvad nu hvis man kunne opnå politisk indflydelse, uden at det føltes som politik? Blandede man idrætten ind i politik, hvis det blot drejede sig godt kammeratskab? Var det politik, hvis man gjorde en god sportskammerat en tjeneste?

Måske skal den venskabsforening, som Arne Elers-Nielsen, der i 1940 var blevet formand for Ballerup Boldklub af 1927, tog initiativ til at danne i 1944, forstås i det lys. Venskabsforeningen, der som formål havde at samle de gamle og ikke længere 
aktive medlemmer, fik navnet Foreningen Til Gamle Ballerup-drenges Ungdomsbevarelse (FTGBU) og blev stiftet den 26. juni 1945. I denne forening samledes mange af de gamle sportskammerater, der havde opnået en alder, hvor de ikke længere aktivt dyrkede sport. Mange af disse sportskammerater havde kendt hinanden siden drengeårene og havde nu opnået en vis social position i Ballerup.

FTGBU havde fra begyndelsen en udpræget selskabelig og uformel karakter med et præg af loge over sig. Foreningen valgte f.eks. en præsident, vicepræsident, $\emptyset$ l-rekvient, marschall, skatmester og skriverkarl.

Ud over at spille oldboys-fodbold og afholde forskellige festlige sammenkomster var FTGBU en vigtig st $\varnothing$ tte for moderklubben Ballerup Boldklub af 1927. I formålsparagraffen stod, at foreningen skulle støtte klubbens fodboldungdom og fremme kammeratskabet og sammenholdet mellem aktive og passive medlemmer. FTBGU så sig selv som et socialt bindemiddel inden for Ballerup Boldklub af 1927.

I kraft af medlemmernes positioner inden for erhvervslivet og deres kontakter til kommunalpolitikere kunne foreningen $\emptyset v e$ indflydelse mange steder.

I 1961 havde Ballerup Idræts Forening (tidligere Ballerup Boldklub af 1927), som beskrevet i begyndelsen af denne artikel, ikke midler til at bygge et større klubhus. Imidlertid havde man FTGBU i baghånden. Netop i forbindelse med klubhuset trådte FTBGU til. I 1963 rettede foreningen en henvendelse til kommunen om forbedring af forholdene. Man tilbød at udvide det daværende klubhus ved hjælp af frivillig arbejdskraft. Til gengæld skulle kommunen betale materialerne, der kostede $40.000 \mathrm{kr}$. FTBGU, der havde mange håndværkere og håndværksmestre som medlemmer, stillede med ekspertise og tekniske tegninger. Kommunalbestyrelsen godkendte forslaget, og arbejdet gik så hurtigt, at man den 12. maj 1964 efter tre måneders arbejde kunne holde rejsegilde. Foreningen havde da haft 45 medlemmer i sving, som tilsammen havde anvendt ca. 2.406 arbejdstimer.

Også ved flere senere sager om anlæggelse af idrætsanlæg greb FTBGU ind i forhandlingerne mellem kommunen og Ballerup Idræts Forening. Det skete f.eks. i 1973 i forbindelse med opførelsen af klubhus og cafeteria ved Ballerup Idrætspark. ${ }^{52}$

Det er vigtigt at forstå, at medlemmerne i FTGBU ikke selv opfattede deres virke som politisk, men som et næsten velgørende arbejde, hvor man naturligt brugte de uformelle og kammeratlige kontakter, man havde i Ballerup - via idrætten. Foreningens medlemmer var netop af forskellig politisk observans, og i det selskabelige samvær så man ikke sig selv som politiske modstandere - eller allierede - men som sportskammerater, der handlede inden for idrættens upolitiske rum.

Spørgsmålet er, om denne form for politisk indflydelse har været udbredt i alle landets kommuner. Mange idrætsforeninger fik fra omkring midten af det 20. århundrede tilknyttet en venskabsforening, der foruden at arrangere bankospil o.1. også kunne gå foreningens ærinder i det kommunalpolitiske. Dette arrangement - som ikke skal forstås som udsprunget af kynisk og gustent overlæg - kom ikke i konflikt med idrætsforeningernes selvforståelse om, at idræt og politik skulle holdes adskilt. Så længe de »politiske« kontakter foregik inden for sportskammeratskabets særlige rum af kækt og muntert uformelt samvær, blev det af de frivillige ledere ikke opfattet som politik - og dermed var indflydelsen moralsk i orden. 
Spørgsmålet er, om ikke denne form for indflydelse på mange måder er essensen $\mathrm{i}$ den måde, hvorpå idrætsforeningerne har udbygget og underbygget deres indflydelse i forhold til de lokale politikere og er- hvervsliv. At deltage i sportens kammeratlige omgangsform var således det samme som at være medlem af en loge, med hvad det indebærer af politisk og $\varnothing$ konomisk netværk. $^{53}$

\section{Noter}

1. Ballerup-Sport, 1961, nr. 3.

2. Især megen af den tyske socialisationsforskning og den franske mentalitetshistorie, som f.eks. Norbert Elias er eksponent for, men også Philippe Aries og Michel Foucault, har beskæftiget sig med det borgerlige individs konstitueringsproces. Elias har beskrevet, hvorledes civilisationsprocessen bestod $i$ en disciplinering af drifterne og den sanselige omverdensrelation og dermed skabelsen af inderliggjorte adfærdsmekanismer. Aries har specielt beskæftiget sig med forestillingerne om barndommen som særskilt epoke i individets udvikling. Foucault har behandlet emner omkring individopfattelse og normalitetsopfattelser, sindssygdom, seksualitet og den sociale kontrol.

3. Se Korsgaard, 1986, s. 96 om sporten som fristed. Amatørbegrebet er tegn på det frie menneske, frie af marked og stat.

4. Netop hele den friskhed og positivitet, som idrætten var pakket ind $i$, gør det vanskeligt i kilderne at finde de konflikter, som sandsynligvis var til stede.

5. Medlemsblad for Fremad Valby, 1940, nr. 5.

6. Ibid., 1944, nr. 10

7. Medlemsblad for Sundby Boldklub, 1943, nr. 1.

8. Ibid., 1949, nr. 2.

9. Ballerup-sport var medlemsblad for Ballerup Idræts Forening.

10. Ballerup-sport, 1947, nr. 5.

11. Ibid., 1950, nr. 9.

12. Ibid., 1950, nr. 12.

13. Medlemsblad for Fremad Valby. Jubilæumsudgave, 1934.

14. Ibid.

15. Ballerup-sport, 1968, nr. 11.

16. Medlemsblad for Fremad Valby, 1936, nr. 2.

17. Maalфv Sport, 1959, nr. 2.

18. Medlemsblad for Fremad Valby, 1949, nr. 5.

18. Ballerup-sport, 1950, nr. 7.

20. Ibid., 1950, nr. 12.

21. Ballerup-sport, 1951, nr. 12.

22. Ballerup-sport, 1952, nr. 8.

23. Ekstra Bladet, 16/1 1958.

24. Ibid.

25. Ibid.

26. VIF-bladet. Medlemsblad for Vanlфse idratsforening, 1958, nr. 1.

27. Ibid.

28. Ibid.

29. Medlemsblad for Kobenhavns Idrats-Forening, 1970, nr. 3.

30. Kai Hartmeyer, 1976, s. 44.

31. Ballerup-spor, 1950, nr. 11.

32. Skive Folkeblad, 29/3 1966.

33. Ibid., 2/11 1966.

34. Medlemsblad for Fremad Valby, 1979.

35. Medlemsblad for Kobenhavns Idrats-Forening, 1954, nr. 6, s. 47.

36. Knud Lundberg, 1990.

37. Ibid., s. 101-102.

38. Frispark - medlemsblad for Skive Idrats Klub, 1946, nr. 4.

39. Sporten. Medlemsblad for Ballerup Gymnastikforening og Ballerup Skytteforening, 1952, nr. 7.

40. Ibid., 1953, nr. 2.

41. Ibid., 1955, nr. 1. Pudsigt er det, at Ballerup Gymnastikforening kaldte deres blad for »Sporten«, når netop begrebet sport repræsenterede de konkurrenceværdier, man tog afstand fra.

42. Skive Folkeblad, 3/6 og 19/6 1944.

43. Ibid., 3/6 1944.

44. Ibid., 19/6 1944.

45. Borgerrepræsentationens forhandlingsprotokol, 22/11 1964, s. 1579.

46. Børge Schmidt kan siges at være Socialdemokratiets idrætspolitiske ordfører. Han var mangeårig medlem af Københavns Idrætspark og en ivrig fortaler for idrætten i København.

47. Borgerrepræsentationens forhandlingsprotokol, 22/10 1964, s. 1592

48. Ibid., s. 182.

49. C'et. Medlemsblad for Det Konservative Folkeparti i Ballerup-Mål $v$-Skovlunde, 1969, nr. 8, s. 1. 
50. C'et. Medlemsblad for Det Konservative Folkeparti i Ballerup - Måløv-Skovlunde, 1972, nr. 2, s. 3.

51 Ibid., nr. 5, s. 1.

52. Ballerup Idrats Forening 15. juni 1927 - 1997. Jubilæumsskrift, 1997, s. 45.

\section{Litteratur og kilder}

Ballerup Idrats Forening 15. juni 1927 - 1997. Jubilæumsskrift (1997).

Ballerup-sport, nr. 5 (1947), nr. 7, 9, 11 og 12 (1950), nr. 12 (1951), nr. 8 (1952), nr. 3 (1961), nr. 11 (1968).

Borgerrepræsentationens (København) forhandlingsprotokol (1964 og 1971).

C'et. Medlemsblad for Det Konservative Folkeparti $i$ Ballerup - Mål $ø$ - Skovlunde, nr. 8 (1969) og nr. 2 (1972).

Ning de Coninck-Smith, For barnets skyld. Byen, skolen og barndommen 1889-1914 (2000).

Ekstra Bladet, 16/1 1958.

Torben Fridberg, Skolebørns fritidsaktiviteter. Kulturog fritidsunders $\phi$ gelsen 1998. Socialforskningsinstitutet (1999).

Frispark - medlemsblad for Skive Idrats Klub, nr. 4 (1946).

Kresten Schultz Jørgensen, De nye barbarer: en bog om det graenseløse Danmark (København, 2000).

Kai Hartmeyer, »På et lille strejftog gennem SIK's 75 år lange historie«. I: Skive Idrats Klub 1901-1976 (Skive, 1976).

Ove Korsgaard, Krop og kultur (1986).

Knud Lundberg, Et liv i leg, (1990).
53. Den verserende sag om Farum Boldklub skal nok også forstås i dette lys. Det samme tema kan sikkert findes landet over, som f.eks. i forholdet mellem tekstilindustrien, partiet Venstre og ishockey i Ikast og Herning.

Karin Lützen, Byen toemmes. Kernefamilie, sociale reformer og velgфrenhed i 1800-tallets København, (1998).

Medlemsblad for Fremad Valby, nr. 2 (1936), nr. 5 (1940), nr. 10 (1944), nr. 5 (1949).

Medlemsblad for Fremad Valby. Jubilæumsudgave (1934).

Medlemsblad for Kфbenhavns Idrcets-Forening, nr. 6 (1954), nr. 3 (1970).

Medlemsblad for Sundby Boldklub, nr. 1 (1943), nr. 2 (1949).

Maaløv Sport, nr. 2 (1959).

Laila Ottesen og Bjarne Ibsen, Idrat, motion, og hverdagsliv - i tal og tale, (1999).

Laila Ottesen, Bjarne Ibsen, Inge Høck og Inger Marie Schmidt, Kultur- og fritidsunders $\phi$ gelsen $i \mathrm{Her}$ lev Kommune, (2001).

Skive Folkeblad, 19/6 1944, 2/11 1966, 29/3 1966 og 3/6 1944.

Sporten. Medlemsblad for Ballerup Gymnastikforening og Ballerup Skytteforening, nr. 7 (1952), nr. 2 (1953), nr. 1 (1955)

VIF-bladet. Medlemsblad for Vanløse idratsforening, nr. 1 (1958). 